\title{
Efektivitas Pembelajaran Berbasis Masalah untuk Meningkatkan Prestasi dan Pemahaman Materi Ilmu Pengetahuan Alam pada Siswa Kelas VII MTSN 9 Jember \\ (Effectiveness of Problem Based Learning to Increase Achievement and Understanding of Natural Sciences Material of VIIth Grades Students of MTSN 9 Jember )
}

\author{
Nur Aliyah \\ MTSN 9 Jember \\ E-mail:nanuralivah8@gmail.com
}

\begin{abstract}
Abstrak
Penelitian ini bertujuan untuk meningkatkan prestasi dan penguasaan materi mata pelajaran Ilmu Pengetahuan Alam (IPA). Penelitian yang dilakukan termasuk pada penelitian tindakan kelas yang dilakukan sebanyak tiga kali putaran. Pada pelaksanaannya tiap putaran terdiri atas empat tahapan yakni diantarannya: rencana (planning), tindakan (action), pengamatan (observation), dan refleksi (reflection). Sasaran penelitian ditujukan pada siswa Kelas VIIF MTSN 9 Jember tahun pelajaran 2016/2017. Data yang didapatkan yakni berupa hasil tes, lembar observasi aktifitas belajar siswa. Dan didapatkan hasil data sebagai berikut: siklus I pertemuan ke 1 $(64,00 \%)$, siklus II pertemuan ke $2(76,00 \%)$, siklus III pertemuan ke $3(88,00 \%)$. Kesimpulan penelitian ini adalah PBM pada pelajaran IPA pada Siswa Kelas VIIF MTSN 9 Jember tahun pelajaran 2016/2017 berdampak positif terhadap pembelajaran IPA yang dilakukan sehingga dapat meningkatkan prestasi dan penguasaan materi IPA oleh siswa, serta model pembelajaran ini dapat digunakan sebagai salah satu alternatif pembelajaran IPA di kelas untuk mengatasi permasalahan yang terjadi ketika pembelajaran berlangsung
\end{abstract}

Kata Kunci : Prestasi Belajar, Pembelajaran Berbasis Masalah, Pélajaran IPA.

\section{Abstract}

This study aims to improve the achievement and mastery of Natural Science subject matter. The research conducted included in the classroom action research conducted three times. In the implementation, each round consists of four stages, namely : planning, action, observation, and reflection. The research target is aimed at students of class VIIth MTSN 9 Jember 2016/2017 academic year. The data-obtained is in the form of test results, observation sheets of student learning activities. Based on the results of the study, the results of the data are as follows: cycle I meeting 1 (64.00\%), cycle II meeting 2 (76.00\%), cycle III meeting $3(88.00 \%)$. The conclusion of this study is that Problem-Based Learning in Science lessons for Grade VIIth MTSN 9 Jember students in 2016/2017 school year has a positive impact on science learning that is done so that it can improve the achievement and mastery of science materials by students, and this learning model can be used as an alternative learning natural science in class to overcome problems that occur when learning takes place

Keywords : Learning Achievement, Problem Based Learning, Natural Sciences

\section{Pendahuluan}

Belajar merupakan sebuah upaya yang dilakukan oleh manusia untuk memperoleh suatu perubahan tingkah laku yang baru, bentuk dari hasil pengalaman pribadi ketika berinteraksi dengan lingkungannya [1]. Selanjutnya, pengertian dari belajar dipertegas lagi sebagai proses perubahan tingkah laku manusia karena adanya kemampuan mereka dalam berinteraksi antara individu dengan lingkungannya [2]. Sedangkan menurut Winkel belajar ini merupakan aktivitas mental/psikis yang terjadi ketika berinteraksi secara aktif dengan lingkungan, yang menghasilkan perubahan-perubahan dalam pemahaman, keterampilan, pengetahuan dan wawasan serta nilai sikap manusia. Perubahan- perubahan itu bersifat relatif konstan[3].
Berdasarkan uraian pendapat tersebut disimpulkan bahwa definisi belajar yakni suatu proses yang dilakukan oleh individu manusia untuk memperoleh suatu tahapan perubahan tingkah laku manusia yang bersifat relatif konstan berupa pemahaman, keterampilan, pengetahuan dan wawasan serta nilai sikap manusia sebagai hasil pengalaman sendiri kaitannya dalam berinteraksi dengan lingkungannya.

Menurut Mappa dan Balessaman pembelajaran adalah usaha sistematik untuk membantu peserta didik melakukan akitivitas belajar supaya mereka memiliki kemampuan mengubah, mengembangkan atau mengendalikan sikap dan perilakunya sampai batas kemampuan yang maksimal [4]. Pendapat lain dikemukakan oleh Hamalik pembelajaran itu merupakan suatu perpaduan unsur manusiawi, material, fasilitas, perlengkapan, dan tahapan yang saling mempengaruhi demi mencapai tujuan pembelajaran itu sendiri[5]. Jadi kesimpulannya dari penjabaran diatas yakni 
pembelajaran merupakan usaha yang sistematik dilakukan oleh pendidik untuk membantu peserta didiknya melakukan aktivitas belajar agar peserta didik mampu mengubah, mengembangkan serta mengendalikan sikap dan perilakunya yang dimiliki guna tercapainya suatu tujuan dari kegiatan belajar.

Prestasi bisa diartikan sebagai suatu hasil yang dicapai oleh individu seseorang setelah mereka melakukan aktivitasnya. Dalam sebuah proses pembelajaran, prestasi belajar berarti acuan pencapaian tingkat penguasaaan materi yang dilakukan peserta didik di dapatkan dari sebuah proses pengukuran. Sedangkan definisi pembelajaran berdasarkan Kamus Besar Bahasa Indonesia (2001:895), prestasi belajar merupakan penguasaan pengetahuan atau keterampilan belajar sesorang, umumnya ditunjukkan melalui nilai hasil tes yang diberikan oleh pendidik. Menurut Winkel sendiri berpendapat tentang prestasi belajar, berdasarkan kemampuan internal yang didapatkan oleh peserta didik sesuai pada tujuan instruksional, yang memunculkan sebuah hasil belajar peserta didik[3]. Sehingga dapat disimpulkan bahwa prestasi belajar itu merupakan suatu hasil belajar yang dicapai oleh peserta didik setelah melakukan proses pembelajaran yang ditunjukkan melalui angka nilai pada hasil tes belajar yang diberikan oleh pendidik.

Wahyana berpendapat Ilmu Pengetahuan Alam (IPA) didefinisikan sebagai suatu gambaran kumpulan pengetahuan manusia yang tersusun sistematik, dan penggunannya secara umum terbatas kaitannya pada gejala alam[6]. Sedangkan menurut H.W Flowler Ilmu Pengetahuan Alam (IPA) adalah pengetahuan manusia yang sistematik dan dirumuskan dengan segala yang berhubugan dengan gejala kebendaan alam yang didapatkan dari hasil observasi dan dedukasi[6]. Perkembangan Ilmu Pengetahuan Alam (IPA) sendiri tak hanya ditandai dengan adanya sebuah fakta, tetapi juga karena adanya sikap ilmiah dan metode ilmiah. Pengamatan ilmiah dan metode ilmiah ini menekankan pada sebuah hakikat IPA yang seutuhnya.

Berdasar paparan definisi tersebut di atas kesimpulannya adalah prestasi belajar pada materi pelajaran IPA itu merupakan nilai yang didapatkan oleh peserta didik setelah melakukan aktivitasnya secara langsung dengan seluruh potensi yang dimilikinya baik aspek pengetahuan (kognitif), sikap (afektif) dan keterampilan (psikomotor) dalam proses pembelajaran IPA berlangsung.

Salah satu alternatif pembelajaran yang diyakini dapat meningkatkan prestasi dan penguasaan materi oleh siswa adalah menggunakan pembelajaran yang berbasis masalah. Pembelajaran berbasis masalah sendiri merupakan pembelajaran yang konteksnya menggunakan masalah yang berhubungan dengan kehidupan nyata. Suatu proses dimana peserta didik belajar, baik ingatan ataupun keterampilan berpikir, dengan fokus memecahkan masalah yang nyata, kerja sama dengan kelompoknya, memberi umpan balik, terjadi kegiatan diskusi, dan membuat suatu laporan akhir atau hasil diskusi bersama. Pembelajaran berbasis masalah itu adalah pembelajaran yang menerapkan teori konstruktivisme[7]. Pembelajaran yang menerapkan model pembelajaran berbasis masalah ini, siswa dapat mengaktifkan informasi baru berdasarkan struktur pengetahuan yang mereka miliki [8].
Peran guru disini dalam pengajaran berbasis masalah yakni sebagai penyaji suatu masalah, tak hanya itu guru juga mengajukan sebuah pertanyaan kepada peserta didik, dan memfasilitasi mereka dalam penyelidikan dan diskusi ketika berlangsung. Pengajaran berbasis masalah iini tidak dapat dilaksanakan dengan lancar tanpa adanya guru yang mempunyai kemampuan untuk mengembangkan situasi dan kondisi tempat berlangsungnya pembelajaran yang memungkinkan adanya pertukaran ide/pendapat secara bebas dan terbuka. Secara umum pengajaran berbasis masalah terdiri dari menyajikan masalah yang berkaitan dengan kehidupan nyata kepada peserta didik sehingga dapat memberikan kemudahan kepada mereka untuk melakukan penyelidikan secara mandiri sehingga pembelajaran tersebut menjadi lebih bermakna.

Keberhasilan dari pembelajaran berbasis masalah (PBM) untuk segala tujuan telah dibuktikan oleh para peneliti salah satu diantaranya yakni penelitian yang dilakukan oleh Capon pada tahun 2004. Penelitiannya memberi sebuah pernyataan bahwa pembelajaran yang berbasis masalah memiliki dampak yang positif terhadap hasil prestasi akademik, sikap mereka dalam proses belajar serta berdampak pada perkembangan konspetual yang dimiliki oleh siswa. Sehingga diyakini bahwa pembelajaran yang menggunakan model pembelajaran berbasis masalah ini tak hanya mampu mengembangkan kemampuan berpikir siswa, tetapi juga berpengaruh terhadap perkembangan sikap siswa menjadi pribadi sosial yang lebih baik, mandiri dan bertanggung jawab. Sehingga hal ini menjadi bekal mereka ketika bermasyarakat nanti.

Menurut Magued Iskander pembelajaran berbasis masalah memiliki lima tahapan utama[9]. Lima tahapan diantaranya yakni 1) Orientasi siswa kepada masalah, 2) Mengorganisasi siswa untuk belajar, 3) Membimbing penyelidikan individual dan kelompok 4) Mengembangkan dan menyajikan hasil karya, 5) Menganalisis dan mengevaluasi proses pemecahan masalah.

Tabel1. Aktivitas Guru pada Tiap Tahap

\begin{tabular}{|l|c|}
\hline \multicolumn{1}{|c|}{ Tahapan } & Aktivitas Guru dalam Pembelajaran \\
\hline $\begin{array}{l}\text { Tahap 1 } \\
\text { Orientasi siswa } \\
\text { kepada masalah }\end{array}$ & $\begin{array}{c}\text { Guru menjelaskan tujuan utama dari } \\
\text { pembelajaran,menjelaskan } \\
\text { perlngkapan yang } \\
\text { dibutuhkan,memotivasi siswa agar } \\
\text { terlibat aktif dalam pemecahan } \\
\text { masalah yang menjadi pilihan. }\end{array}$ \\
\hline $\begin{array}{l}\text { Tahap 2 } \\
\text { Mengorganisasi } \\
\text { siswa untuk belajar }\end{array}$ & $\begin{array}{c}\text { Guru membantu siswa } \\
\text { mendefinisikan dan } \\
\text { mengorganisasikan tugas belajar } \\
\text { yang berhubungan dengan masalah } \\
\text { yang terkait. }\end{array}$ \\
\hline $\begin{array}{l}\text { Tahap 3 } \\
\text { Membimbing } \\
\text { penyelidikan } \\
\text { individual kelompok }\end{array}$ & $\begin{array}{c}\text { Guru mendorong siswa untuk } \\
\text { mengumpulkan segala informasi } \\
\text { materi,melaksanakan eksperimen } \\
\text { dengan kelompoknya,untuk } \\
\text { mendapatkan penyelesaian dan }\end{array}$ \\
pemecahan masalah dengan diskusi \\
bersama.
\end{tabular}




\begin{tabular}{|l|c|}
\hline $\begin{array}{l}\text { Tahap 4 } \\
\text { mengembangkan dan } \\
\text { karya }\end{array}$ & $\begin{array}{c}\text { Guru membantu siswa untuk } \\
\text { menyiapkan dan merencanakan } \\
\text { hasil diskusi kelompok yang berupa } \\
\text { hasil karya yang cocok contohnya } \\
\text { berupa video, laporan, dan model } \\
\text { serta guru membantu siswa berbagi } \\
\text { tugas bersama teman } \\
\text { sekelompoknya.Serta memberi } \\
\text { dorongan agar mereka dapat } \\
\text { menyajikan hasil karya di depan } \\
\text { kelas dengan baik dan benar. }\end{array}$ \\
\hline $\begin{array}{l}\text { Tahap 5 } \\
\text { Menganalisa dan } \\
\text { mengevaluasi proses } \\
\text { pemecahan masalah } \\
\text { melakukan kegiatan evaluasi atau } \\
\text { refleksi terhadap observasi mereka } \\
\text { dan aktivitas yang mereka lakukan } \\
\text { selama proses pembelajarann } \\
\text { berlangsung. }\end{array}$ \\
\hline
\end{tabular}

Tujuan pembuatan penelitian yang dilakukan yakni diharapkan dapat meningkatkan sebuah prestasi belajar dan penguasaan materi pelajaran IPA siswa kelas VIIF MTSN 9 Jember, selama proses berlangsung guru berperan penuh terlibat dalam penelitian mulai dari tahap perencanaan (planning), tahap tindakan (action), tahap pengamatan (observation), dan tahap refleksi (reflection).

Manfaat Penelitian yang dilakukan ini diantaranya adalah (1) Bagi peneliti, sebagai wawasan dan pengetahuan baru mengenai peranan guru dalam usaha meningkatkan prestasi dan penguasaan materi pelajaran IPA, serta memberikan pengalaman dalam mengembangkan pembelajaran yang inovatif khususnya pelajaran IPA; (2) Bagi siswa, sebagai sarana untuk meningkatkan prestasi dan pemahamannya dalam pelajaran IPA.

\section{Metode Penelitian}

Penelitian yang dibuat tergolong pada penelitian tindakan kelas (PTK), dimana penelitian yang dilakukan dimaksudkan untuk memecahkan sebuah masalah (problem) pembelajaran yang terjadi di kelas. Penelitian ini juga berjenis penelitian deskriptif kualitatif, sebab menggambarkan bagaimana suatu teknik pembelajaran diterapkan dan bagaimana hasil yang diinginkan dapat dicapai. Pelaksanaannya dilakukan dalam tiga siklus. Selama proses penelitian berlangsung guru sebagai peneliti, dan juga penanggung jawab penuh penelitian ini adalah guru. Instrumen yang dipakai berupa silabus, rencana pelaksanaan pembelajaran (RPP), dan tes formatif. Data-data yang diperlukan dalam penelitian ini diperoleh melalui observasi (observation) pengolahan pembelajaran kontekstual model pengajaran berbasis masalah, dan tes formatif. Sedangkan hasil belajar yang diukur meliputi tentang nilai kognitif dan afektif dari siswa. Peningkatan hasil belajar kognitif siswa ditunjukkan dengan angka kenaikan persentase siswa yang telah menjawab benar pada butir soal yang diberikan. Hasil belajar afektif siswa ditunjukkan dengan melihat sifat positif dan negatif yang muncul ketika pembelajaran sedang berlangsung.

Tingkat keberhasilan atau persentase keberhasilan siswa dianalisis setelah mereka melakukan proses belajar mengajar setiap putarannya yang dilakukan dengan cara memberikan evaluasi berupa soal tes tertuliss di akhir putaran. Analisis ini menggunakan metode perhitungan statistik sederhana yakni:

1. Untuk penilaian ujian berupa tes formatif

$$
\bar{X}=\frac{\sum X}{\sum N}
$$

keterangan : $\quad \bar{X}=$ Nilai rata-rata dari siswa

$$
\begin{aligned}
& \sum X=\text { Jumlah semua nilai dari siswa } \\
& \sum N=\text { Banyaknya jumlah siswa }
\end{aligned}
$$

2. Untuk penilaian ketuntasan belajar siswa

$$
P=\frac{\sum \text { siswa yang tuntas belajar }}{\sum \text { siswa }} \times 100
$$

Langkah-langkah dalam penelitian ini dibagi ke dalam empat tahap, secara berurutan diantaranya adalah (1) rencana (planning), (2) tindakan (action), (3) pengamatan (observation), (4) refleksi (reflection). Tahap pertama adalah planning (rencana), meliputi pembuatan atau penyusunan sebuah rumusan masalah, tujuan dan membuat rencana tindakan, termasuk di dalamnya perangkat pembelajaran dan instrumen penelitian. Tahap action (tindakan), meliputi kegiatan yang dilakukan oleh peneliti sebagai usaha untuk membangun pemahaman konsep dari siswa serta mengamati dampak yang muncul akibat dari penerapan metode pembelajaran yang berbasis masalah tersebut. Tahap observation (pengamatan), meliputi kegiatan peneliti untuk mengkaji, melihat dan menilai hasil atau dampak dari tindakan (action) yang telah dilakukan berdasarkan lembar observasi yang diisi oleh pengamat.Tahap akhir yaitu reflection (refleksi), pada tahapan ini peneliti dan pengamat merefleksi dalam sebuah diskusi hasil dari semua perencanaan, tindakan dan pengamatan yang dilakukan sebelumnya kemudian hasil dari kegiatan refleksi ini digunakan untuk membuat atau memodifikasi suatu rancangan yang direvisi untuk dilakukan pada siklus selanjutnya.

\section{Hasil dan Pembahasan}

Hasil dari penelitian diambil dari dua observasi, pertama yakni mengenai observasi terhadap pengelolaan metode pembelajaran berbasis masalah yang berguna untuk mengetahui pengaruh penerapan metode pembelajaran berbasis masalah dalam usaha peneliti untuk meningkatkan prestasi belajar dan penguasaan materi oleh siswa, yang kedua adalah observasi terhadap aktivitas siswa dan guru dalam proses pembelajaran berlangsung.

Analisis data tes formatif dilakukan untuk mengetahui prosentase peningkatan prestasi belajar siswa penguasaan terhadap materi setelah diterapkan pembelajaran berbasis masalah pada pelajaran IPA ini. Berikut tabel mengenai hasil tes formatif siswa kelas VIIF MTSN 9 Jember tahun pelajaran 2016/2017: 
Tabel 1 Rekapitulasi Hasil Analisis Tes Formatif pada Siklus I, II, dan III

\begin{tabular}{|c|c|c|c|c|}
\hline No & Uraian & $\begin{array}{c}\text { Hasil } \\
\text { Siklus I }\end{array}$ & $\begin{array}{c}\text { Hasil } \\
\text { Siklus II }\end{array}$ & $\begin{array}{c}\text { Hasil } \\
\text { Siklus III }\end{array}$ \\
\hline 1 & $\begin{array}{c}\text { Nilai } \\
\text { rata-rata tes } \\
\text { formatif }\end{array}$ & 66,40 & 71,20 & 77,20 \\
\hline 3 & $\begin{array}{c}\text { Jumlah } \\
\text { siswa yang } \\
\text { tuntas belajar }\end{array}$ & 16 & 19 & 22 \\
\hline 3 & $\begin{array}{c}\text { Presentase } \\
\text { ketuntasan } \\
\text { belajar }\end{array}$ & 64,00 & 76,00 & 88,00 \\
\hline
\end{tabular}

Pelaksanaan kegiatan belajar mengajar untuk siklus I dilakukan pada tanggal 4 Oktober 2017 di kelas VIIF yang berjumlah 25 siswa. Dalam hal ini peneliti bertindak sebagai guru dan membutuhkan bantuan pengamat (observer) untuk mengamati berlangsungnya proses belajar mengajar di kelas. Pengamatan (observasi) ini dilakukan seiring berjalanya proses belajar mengajar mulai awal hingga akhir pelajaran. Di awal pembelajaran siswa masih beradaptasi dengan pemberlajaran yang dilakukan, sehingga terdapat sedikit keraguan siswa dalam melakukan aktifitas pembelajaran. Proses pembelajaran yang telah dilakukan mengacu pada rencana awal pembelajaran yang telah dipersiapkan sebelumnya.

Dimana guru mempunyai andil yang sangat besar untuk menjadi fasilitator mereka. Dengan berbantuan projector siswa dipaparkan sebuah masalah yang berkaitan dengan kehidupan nyata di awal pembelajaran. Pemberian tes formatif I dilakukan di akhir proses pelajaran dimaksudkan untuk mengetahui tingkat keberhasilan dari siswa dalam proses pembelajaran yang telah dilakukan. Hasil analisis memaparkan bahwa terdapat 16 siswa yang memperoleh nilai diatas KKM dan terdapat 9 siswa yang belum tuntas pada tes formatif ini. Nilai rata-rata dari tes formatif pada siklus pertama adalah 66,40 .

Pelaksanaan aktivitas pembelajaran pada siklus II dilaksanakan pada tanggal 11 Oktober 2017 dan masih tetap menggunak kelas VIIF yang berjumlah 25 siswa. Peranan peneliti masih tetap seperti siklus I yakni bertindak sebagai guru dan dibantu oleh observer dalam pengamatan pembelajaran berlangsung. Rancangan awal proses pembelajaran siklus II ini sama dengan siklis 1 yani mengacu pada rencana awal pembelajaran dengan menganalisis dan memperbaiki beberapa revisi pada siklus I, sehingga kesalahan atau kekurangan yang terjadi pada siklus I tak terulang kembali. Pada siklus II siswa sudah mulai memahami metode pembelajaran yang dilakukan sehingga mereka tidak ragu untuk melakukan tahap demi tahap aktivitas. Suasana sangat aktif ditunjukkan dengan respon positif mereka mulai dari aktifitas bertanya kepada teman, guru dan kegiatan diskusi, baik kelompok maupun diskusi kelas serta dalam penyajian hasil karya mereka di depan kelas.

Observer melakukan pengamatannya mulai dari awal hingga akhir pembelajaran. Pemberian tes dilakukan di akhir pembelajaran, yakni siswa diberi tes formatif II dengan maksud untuk mengetahui tingkat keberhasilan siswa dalam proses belajar mengajar pada siklus ke ini. Hasil analisis menunjukkan bahwa ada 6 siswa yang belum tuntas dan 19 siswa diatas KKM yang artinya tuntas belajar dalam tes formatif II. Yakni menunjukkan terdapat peningkatan prestasi belajar siswa dengan adanya perubahan jumlah siswa tuntas belajar pada siklus I ke tahap siklus II yakni dari 16 siswa berubah menjadi 19 siswa. Nilai rata-rata dari tes formatif II pada siklus II adalah 71,20.

Pelaksanaan siklus III dilaksanakan tanggal 18 Oktober 2017 di kelas VIIF yang berjumlah 25 siswa. Peran guru dan pengamat masih sama seperti siklus sebelumnya. Dan aktifitas pembelajaran tetap mengacu pada rencana pelajaran dengan memperhatikan beberapa revisi-revisi pada siklus II, sehingga dapat meminimalisir terjadinya kesalahan lagi pada siklus III ini dan kesalahan pada siklus sebelumnya tidak terulang kembali. Pemberian tes formatif III di akhir pembelajaran pada siklus III ini yang bertujuan untuk mengetahui tingkat keberhasilan siswa dalam proses pembelajaran yang telah dilakukan. Terdapat 3 siswa yang tidak tuntas belajar dan 22 siswa tuntas belajar. Dari analisis data menunjukkan peningkatan yang signifikan yakni dari 19 síswa yang tuntas pada siklus II menjadi 22 siswa yang tuntas pada siklus siklus III. Nilai rata-rata dari tes formatif III adalah 77,20.

Peneilitian ini menunjukkan hasil bahwa pembelajaran yang dipilih yakni pembelajaran model berbasis masalah memiliki banyak dampak positif bagi siswa dalam upaya meningkatkan daya ingat, perkembangan sikap, dan pemahaman konsep pelajaran. Hal tampak dari semakin mantapnya pemahaman dan penguasaan siswa terhadap materi pelajaran yang telah disampaikan oleh guru selama pembelajaran berlangsung (ketuntasan belajar semakin meningkat dari siklus I menuju siklus II, siklus II menuju siklus III) yakni masing-masing 64,00\%, 76,00\%, dan $88,00 \%$. Peningkatan dari siklus ke siklus konstan yakni prosentase menunjukkan peningkatan sebanyak $12,00 \%$.

Dengan adanya perubahan peningkatan di tiap siklus ini, membuktikan bahwa dengan menggunakan pembelajaran berbasis masalah ternyata bisa meningkatkan prestasi belajar dan penguasaan materi mata pelajaran IPA. Peningkatan penilaian proses belajar siswa dan prestasi belajar siswa MTSN 9 Jember di kelas VIIF dapat dilihat pada tabel histogram hasil siklus I,II, dan III dibawah. Berdasarkan analisis yang dilakukan didapatkan data bahwa aktivitas siswa dalam proses pembelajaran berbasis masalah di pelajaran IPA kelas VII di setiap siklus mengalami peningkatan. Hal ini berdampak baik terhadap proses mengingat kembali materi pelajaran IPA yang telah diterima selama proses pembelajaran, ditunjukkan dengan meningkatnya nilai rata-rata siswa pada setiap siklus yang terus mengalami peningkatan.

Berdasarkan analisis data, diperoleh aktivitas siswa dalam proses pembelajaran IPA dengan pembelajaran berbasis masalah yang paling dominan adalah dengan sigap mereka bekerja dengan menggunakan alat/media, aktif ketika dilakukan kegiatan diskusi antar siswa/antara siswa dengan guru baik kelompok maupun diskusi kelas, dan mendengarkan/memperhatikan penjelasan guru dengan 

lebih matang. Jadi dapat dikatakan bahwa aktivitas siswa MTSN 9 Jember kelas VIIF tahun pelajaran 2016/2017 dapat digolongkan menjadi pembelajaran yang aktif dan pembelajaran yang bermakna.

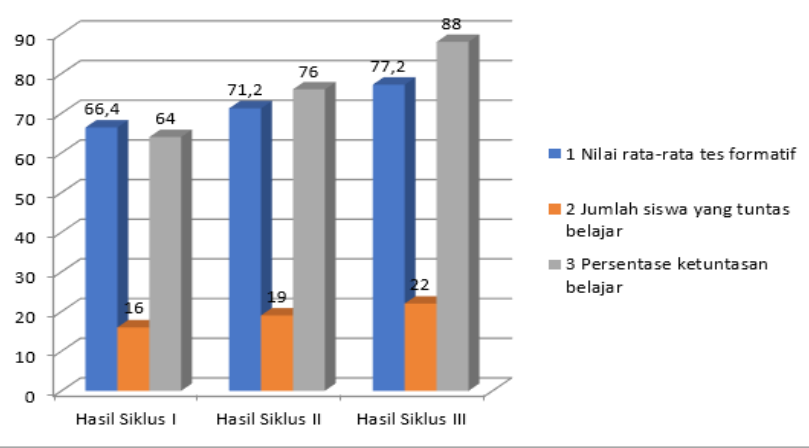

Gambar 1. Perbandingan tiap siklus

Sedangkan untuk aktivitas guru selama pembelajaran telah melaksanakan langkah-langkah metode pembelajaran berbasis masalah dengan baik. Dimulai dengan memberikan tahap orientasi siswa sampai tahap evaluasi masalah. Hal tampak pada aktivitas guru yang muncul di antaranya aktivitas mengamati dan membimbing siswa dalam setiap mengerjakan tugas kelompok ataupun mandiri, menjelaskan tentang cara penggunaan alat media pembelajaran, memberikan sebuah umpan balik/tanya jawab/evaluasi terhadap siswa. Sehingga peranan guru disini sangat berperngaruh terhadap pembelajaran yang berlangsung. Prosentase yang didapat untuk aktivitas guru sangat tinggi dimana semua tahap hampir terselesaikan dengan baik. seksama. Mereka juga dapat mentoleransi adanya perbedaan pendapat sehingga muncul adanya perkembangan sikap yang

masalah di pelajaran IPA, sehingga mereka menjadi termotivasi untuk semangat belajar.

3. Pembelajaran berbasis masalah memiliki dampak positif terhadap pemahaman materi pelajaran IPA yang diajarkan, dengan metode ini mereka dipaksa untuk memecahkan masalah yang beruhubungan dengan materi palajaran IPA dikaitkan dengan kehidupan nyata dengan terkonsep, baik itu tugas individu dan maupun tugas kelompok.

Agar proses belajar mengajar IPA berlangsung maksimal dan lebih efektif, maka perlu adanya beberapa saran sebagai berikut ini:

1. Pada saat melaksanakan metode PBM ini diperlukan sebuah persiapan yang matang, agar segala sesuatu dapat berjalan dengan baik disini guru harus mempunyai kemampuan untuk memilih dan menentukan sebuah topik yang cocok untuk diterapkan dengan PBM dalam proses pembelajaran sehingga hasilnya optimal.

2. Upaya dalam meningkatkan prestasi belajar dan pemahaman materi IPA, guru harusnya lebih sering melatih siswa dengan macam-macam metode pengajaran yang sesuai, walaupun pengajaran tersebut cukup sederhana, harapannya siswa dapat menemukan pengetahuan dan wawasan baru, memperoleh konsep dan keterampilan, sehingga siswa berhasil atau mampu memecahkan masalah-masalah yang dihadapinya.

3. Perlu adanya penelitian yang lebih lanjut, karena hasil penelitian ini hanya dilakukan di MTSN 9 Jember Kelas VII F Tahun Pelajaran 2016/2017.

\section{Daftar Pustaka}

[1] Slameto. 1995. Belajar Dan Faktor-Faktor Yang Mempengaruhinya. Jakarta: PT Rineka Cipta

[2] Usman. 2000. Ilmu Pedagogik. PT. Remaja Rosdakarya

Kesimpulan dan Saran

[3] Supriyono. 2013. Pengembangan Perangkat Pembelajaran Matematika Berbasiss Student Facilitator And Explaining (SFAE) Dengan Setting Contextual Teaching And Learning (CTl) Pada Sub Pokok Bahasan Prisma dan Limas Kelas VII Semester Genap . Jember: Universitas Jember [skripsi tidak diterbitkan].

Berdasarkan hasil penelitian yang telah dilakukan selama tiga siklus ini, serta berdasarkan seluruh hasil analisis dan pembahasan yang telah dilakukan didapatkan disimpulkan sebagai berikut:

1. Pembelajaran IPA yang menggunakan pembelajaran

berbasis masalah ini berdampak baik/positif terhadap hasil pembelajaran yang dilakukan di MTSN 9 Jember kelas VIIF dengan berjumlah 25 siswa tahun pelajaran 2016/2017, sehingga dapat meningkatkan prestasi belajar dan penguasaan materi siswa terhadap pelajaran itu sendiri yang ditandai dengan peningkatan ketuntasan belajar siswa dalam setiap siklusnya, yaitu siklus I $(64,00 \%)$, siklus II $(76,00 \%)$, siklus III $(88,00 \%)$. Prosentase peningkatan ketuntasan belajar berjalan konstan di setiap siklus ke siklus yakni $12,00 \%$.

2. Penerapan pembelajaran berbasis masalah pada pelajaran IPA yang telah dilakukan di kelas VIIF MTSN 9 Jember tahun pelajaran 2016/2017 ini mempunyai pengaruh positif, yaitu dapat meningkatkan prestasi belajar siswa untuk mempelajari materi pelajaran yang di dapatkan, hal ini ditunjukan dengan rata-rata sikap siswa yang menyatakan bahwa siswa tertarik dan berminat dengan pembelajaran berbasis
[4] Mappa dan Ballesman. 1994. Teori Belajar Orang Dewasa.Jakarta:Depdikbud.

[5] Hamalik, Oemar. 2003. Kurikulum dan Pembelajaran. Jakarta: Bum Aksara.

[6] Trianto. 2010. Model Pembelajaran Terpadu Konsep, Strategi, dan Implementasinya (KTSP). Jakarta: Bumi Aksara.

[7] Utami, Yudy Tri. 2017. Pengembangan Perangkat Pembelajaran Matematika Berbasis Problem Based Learning Bernuansa Islami Untuk Mengukur Kemampuan Berpikir Kritis Siswa pada Pokok Bahasan Barisan dan Deret. Jember: Universitas Jember [tesis tidak diterbitkan].

[8] Capon, Noel. 2004. What's So Good About Problem-Based Learning. Cognition And Instruction, 22(1): 61-79, diakses 19 Mei 2017.

[9] Fathurrohman, M. 2004. Model-model Pembelajaran Inovativ Alternatif Desain Pembelajaran yang Menyenangkan. Yogyakarta: Ar-ruzz Media. 